\title{
ORGANOLEPTIC PROPERTIES AND SOME MINERALS OF JUNKET (A SWEET DESSERT) FORTIFIED WITH HUSK TOMATO SEEDS POWDER.
}

\author{
Amal M.M. El-Nimer
}

Dairy Technology Research Department, Animal Production Research Institute, Agricultural Research Center, Dokki, Giza, Egypt.

\section{ABSTRACT}

Junket was prepared from fresh retentate buffalo's milk (FRBM)

as follows: Treatment (1): $\mathbf{F R B M}+15 \%$ sucrose + vanilla (control). Treatment (2): FRBM+15\%, sucrose+ vanilla $+5 \%$ husk tomato

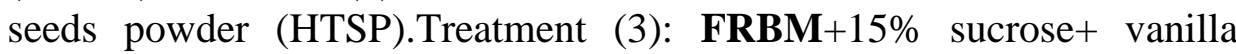
$+10 \%$ HTSP.Treatment (4): FRBM+15\%sucrose+ vanilla $+15 \%$ HTSP. The Literature mentioned that husk tomato seeds Powder was rich in the chemical composition and antioxidant activity (55.09\%), besides some minerals e.g.. cobalt, copper, iron, zinc, selenium and manganese. A direct relationship was observed between the percent of (HTSP) added and the concentrations of the estimated minerals, this means that as the ratio of (HTSP) increased the concentrations of the former elements increased. Sensory evaluation revealed that all junkets were, generally, acceptable and had approximately similar properties in its texture and appearance. Junket desserts made from (FRBM) and fortified with husk at a rate of 5 or $10 \%$ were found the superior rand had total scores similar to control, while the treatment with 15\% (HTSP) had the lowest scores and was slightly inferior than the former ones. It is advised to use HTSP in the production of junket and other dairy products to increase both its nutrional value and antioxidant activity.

\section{INTRODUCTION}

Junket is a sweet dessert made of flavored milk, curdled with rennet and made in some world countries. It is desired among people of different ages: infants, children, adults and elderly people. This product is consumed daily, due to its pleasant taste and satiating power. It is similar to rice dessert made in India by boiling the milk with rice and sugar (Mathur et al., 1985). Limited data are available about the manufacturing and properties of junket dessert.

Nowadays, consumers are gradually shifting towards the consumption of natural fruit or vegetable because of their high nutritional values, medicinal importance, and good caloric source, (Ramadan et al., 2011 and Hemalatha et al., 2018). Many countries through the world have been detected the magnitude of fruit or vegetable as a cheap means 
of preservation, promoting nutritional quality and consolidating sensory characteristics (Marsh et al., 2014).

Husk tomato (Physalis Pubescens L), have different names such as husk tomato , strawberry tomato, tomatillo fruit, golden berry or winter cherry ( Swartwood and Van Eck, 2019) and known commonly in Egypt as Harankish. It's usually used for local consumption as a snake food or for exportation. The fruit of Harankish are perishable because of its high moisture content which leads to a rapid spoilage if it doesn't use. Additionally, Harankish is very acceptable and popular for its sweet taste, acidic nature, and high nutritive value, therefore its consumption in Egypt starting to increase. Moreover, many factories have been processing husk tomato into different foodstuffs as Jelly and Jam and you can see these products on the market shelfs. Seeds of husk tomato are representing approximately 30\% of the fruit (Etzbach et al., 2018 and Guimaraes et al., 2019).

Fortification of food is very vital process, definite as the adding of one or extra nutrients together to increase the nutritional value of food, functional properties as well as sensory assessment, (Abouel-Yazeed, et al.2019).

Little data are valuable in the literatures regarding the use of tomato husk seeds in the field of dairy products; therefore, the current search was carried out to make Junket enriched with husk tomato seed powder to assess the sense evaluation and some minerals in the final product.

\section{MATERIALS AND METHODS}

Materials \& Methods:

\section{Materials:}

Fresh retentate buffalo's milk was obtained from Dairy Processing Unit, Animal Production Research Institute, Agriculture Research Center, Ministry of Agriculture. The gross composition of fresh retentate buffalos milk (FRBM) is given in Table (1).

Table (1): The gross composition of fresh retentate buffalo's milk (\%).

\begin{tabular}{|c|c|}
\hline Constituent $\%$ & Fresh retentate buffalo's milk \\
\hline Fat & 5 \\
\hline Protein & 19 \\
\hline Lactose & 4.9 \\
\hline Ash & 0.8 \\
\hline Total solid & 30 \\
\hline
\end{tabular}

Fresh husk tomato fruits (Physalis Pubescens L) were obtained from the local market at Giza, Egypt, and prepared as monitored by bouel-Yazeed et al., (2019) . The chemical composition of Husk tomato seeds powder (HTSP) is shown in Table (2) 
Table (2): The chemical composition of husk tomato seeds Powder (HTSP).

\begin{tabular}{|c|c|}
\hline Component (\%) & husk tomato seeds powder* \\
\hline Moisture & 7.65 \\
\hline $\begin{array}{c}\text { Total sugars } \\
\text { ( carbohydrate) }\end{array}$ & 54.85 \\
\hline Crude protein & 15.60 \\
\hline Crude lipid & 18.89 \\
\hline total ash & 2.83 \\
\hline Crude fiber & 33.51 \\
\hline Antioxidant activity & 55.09 \\
\hline Potassium $^{\text {a }}(\mathrm{K})$ & 495.25 \\
\hline $\begin{array}{ll}\text { Sodium }^{\mathrm{a}} & (\mathrm{Na}) \\
\end{array}$ & 129.58 \\
\hline Posphrous $^{\mathrm{a}} \quad$ (P) & 123.75 \\
\hline Iron $^{\mathrm{a}} \quad(\mathrm{Fe})$ & 10.82 \\
\hline
\end{tabular}

Sugar... (sucrose) commercial grade, granulated case, produced by the Sugar and Integrated Industries Co., at Hawamdia, Egypt , Vanilla was obtained from the local market and Rennet powder was obtained from Chr. Hansen Laboratories, Copenhagen, Denmark. Manufacturing of junket:

Usually, to make junket, milk with sugar and vanilla is heated to approximately body temperature and the rennet, which has been dissolved in water, is mixed in to cause the milk to set. The dessert is chilled prior to serving. Junket is often served with a sprinkling of grated nutmeg on top.

Manufacturing of junket from fresh retentate buffalo's milk (FRBM):-

Treatments of Junket under study were prepared from FRBM as follows:

Treatment (1): FRBM+15\% sucrose...........(control ) .

Treatment (2): FRBM+15\% sucrose $+5 \%$ HTSP

Treatment (3): FRBM+15\% sucrose $+10 \%$ HTSP

Treatment (4): FRBM $+15 \%$ sucrose $+15 \%$ HTSP

The resultant mixtures were heat - treated at $85^{\circ} \mathrm{C}$ for $5 \mathrm{~min}$., cooled to $45^{\circ} \mathrm{C}$. renneting $(0.3 \%$ rennet powder $)$ and kept to completely coagulation .

\section{Methods of analysis:}

Fresh retentate buffalo's milk was analysis for its chemical composition by the methods of AOCA (2010). Carbohydrates were calculate by difference FAO/WHO (1998) as $=100-$ (moisture+protein+ fat+ ash) in $100 \mathrm{gm}$ of food. Some mineral as $(\mathrm{Co}, \mathrm{Cu}, \mathrm{Fe}, \mathrm{Zn}, \mathrm{Se}$ and $\mathrm{MN}$ ) were measured according to AOCA (2010).

\section{Organoleptic evaluation:}

The samples of all treatments were examined organoleptically by panel of staff members of the Dairy Technology Department, Animal 
Production Research Institute, according to the score card suggested by Hegazy.et al., (2019).

\section{Minerals:}

\section{RESULTS AND DISCUSSION}

Data mentioned in table (3) showed the concentrations of some elements (Cobalt $\{\mathrm{CO}\}$, Copper $\{\mathrm{Cu}\}$, Iron $\{\mathrm{Fe}\}$, Zinc $\{\mathrm{Zn}\}$, Selenium $\{\mathrm{Se}\}$ and Manganese $\{\mathrm{Mn}\}$ ) of the resultant Junkets made from FRBM with (HTSP). It could be noticed that a direct relationship was observed between the percent of (HTSP) added and the concentrations of the estimated minerals, this means that as the ratio of ( HTSP) increased the concentrations of the former elements increased . 15\% HTSP junket contained the highest concentrations of these elements especially $\mathrm{Fe} \&$ $\mathrm{Zn}$ (which had vital role in the physiological presses took placed in the human body).

Table (3): Some mineral contents of Junket made from retentate buffalo's milk and Fortified with husk tomato seeds powder (HTSP).

\begin{tabular}{|l|c|c|c|c|}
\hline \multirow{2}{*}{ Elements } & & \multicolumn{3}{|c|}{ HTSP } \\
\cline { 3 - 5 } Co* & Control & $5 \%$ & $10 \%$ & $15 \%$ \\
\hline $\mathrm{Cu}^{*}$ & 0.868 & 1.18 & 1.37 & 1.96 \\
\hline $\mathrm{Fe}^{*}$ & 1.195 & 3.075 & 3.94 & 4.74 \\
\hline $\mathrm{Zn} *$ & 1.182 & 4.212 & 7.85 & 9.38 \\
\hline $\mathrm{Se}$ & 2.96 & 4.0 & 6.49 & 8.0 \\
\hline $\mathrm{Mn}$ & \multicolumn{4}{|c|}{ Less than $0.4 \mu \mathrm{g} / \mathrm{g}$} \\
\hline
\end{tabular}

* Mg ( milligram) / Kg

\section{Organoleptic properties:}

Organoleptic properties of junket desserts are presented in Table (4) and Fig. (1). Junket desserts made from retentate buffalo's milk and fortified with Husk at a rate of 5 or $10 \%$ had total scores similar to control (94 points), while the treatment with 15\% (HTSP) had the lowest scores (91.5 points) and was slightly inferior than the former ones. All junkets were generally acceptable and had approximately similar properties in its texture and appearance.

Table (4): Organoleptic scores of Junket made from retentate buffalo's milk and fortified with husk tomato seeds powder (HTSP) .

\begin{tabular}{|c|c|c|c|c|}
\hline \multirow{2}{*}{ Item } & \multirow{3}{*}{ Control } & \multicolumn{3}{|c|}{ HTSP } \\
\cline { 3 - 5 } & $\mathbf{4 8}$ & $\mathbf{5 \%}$ & $\mathbf{1 0 \%}$ & $\mathbf{1 5 \%}$ \\
\hline Flavour (50) & $\mathbf{3 8}$ & $\mathbf{3 7 . 5}$ & $\mathbf{4 7 . 5}$ & $\mathbf{4 5}$ \\
\hline Texture(40) & $\mathbf{8}$ & $\mathbf{8 . 5}$ & $\mathbf{8 . 5}$ & $\mathbf{3 8 . 5}$ \\
\hline Apperance(10) & $\mathbf{9 4}$ & $\mathbf{9 4}$ & $\mathbf{9 4}$ & $\mathbf{9 1 . 5}$ \\
\hline Total & & \multicolumn{3}{|c}{} \\
\hline
\end{tabular}




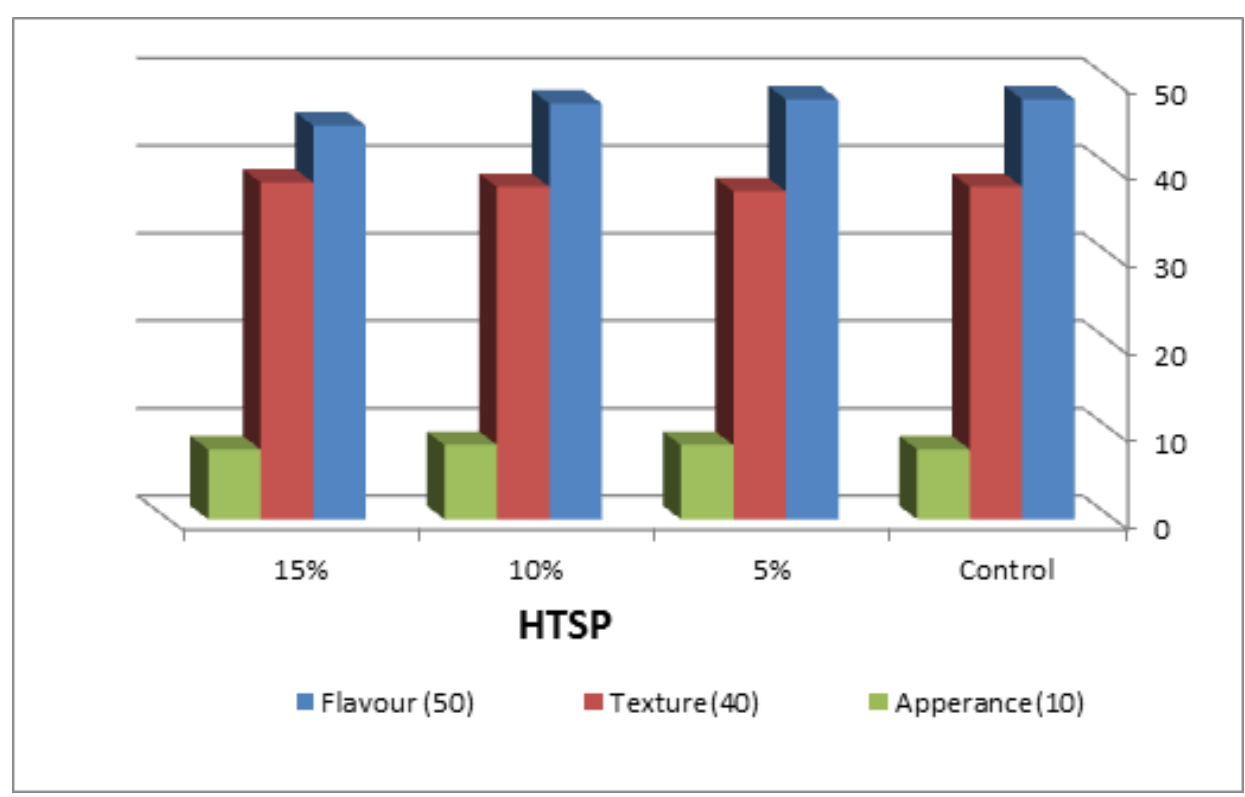

Fig. (1): Organoleptic scores of Junket made from retentate buffalo's milk fortified with Husk tomato seeds powder (HTSP).

\section{CONCLUSION}

Junket, as a dairy dessert made with fresh retentate buffalo's milk and fortified with husk tomato seed powder (HTSP) at a ratio of 5 or 10 $\%$ had similar score points like the control, while junket contained $15 \%$ (HTSP) was slightly inferior than the former ones. They characterized by good flavor, pleasant sweet taste and proper body \& texture.

The above results displayed that husk tomato seed powder had antioxidant activity and was rich in some minerals such as Cobalt, Copper, Iron, and Zinc. So it could be successfully used as a vehicle to delivery and support this type of dessert as well as the other dairy products with the former vital benefits of husk tomato seed powder.

\section{REFERENCES}

Abouel-Yazeed, A.M. ; E.S. Abou-Tor and E.G.Boriy (2019). Utilization of Husk tomato fruit seeds powder in some foodstuff, J. Food and Dairy Sci., Mansoura Univ., 10 (8): 281-288.

AOAC (2010), Analysis of the Association of Official Analytical Chemists (AOAC). International Official Methods. William, H. $17^{\text {th }}$ Ed. Gaithersburg M.D., USA.

Hegazy, Eman, M. ; Afaf O. Ali ; Joda S. El-Sayed and Jihan M. Kassem (2019). Quality Properties of husk tomato juice and its impact in stirred probiotic yogurt, Asian Food Sci. J.,7(2): 1-10. 
Etzbach, L. ; A. Pfeiffer ; F. Weber and A. Schieber (2018). Characterization of carotenoid profiles in golden berry (Physalis peruviana $L$.) fruits at various ripening stages and in different Plant tissues by HPLC-DAD-APCI-MS. Food Chemistry, 245: 508-517.

FAO/WHO,(1998). Carbohydrates in human nutrition. Report of a Joint FAO/WHO Expert Consultation, Rome 14-18 April 1997. Food and Agriculture Organization of the United Nations, Rome.

Guimaraes, D.H. ; G.L. Alves and A.F. Querid (2019). Blueberry Jam: correlation of rheological parameters and water activity with sensorial attributes. Acta Scientiarum Technology, 41: 1-6.

Hemalatha, R. ; A. Kumar ; O. Prakash ; A. Supriya ; A.S. Chauhan and V.B. Kudachikar (2018). Development and Quality evaluation of ready to serve (RTS) beverage from Cape gooseberry (Physalis peruviana L.). Beverages, 4(42): 1-15.

Marsh A.J. ; C. Hill ; R.P. Ross and P.D. Cotter (2014). Fermented beverages with health-promoting potential: past and future perspectives. Trends in food Sci. and Technology, 38,2,113-124.

Mathur, O.N. ; D.C. Bhatacharya and N.K. Roy (1985). Phirni an Indian sweet dish. Indian Dairyman, 3(12): 575-578. C.F. DSA, (1987), 49(1): 24.

Ramadan, M.F. and J.T. MÖrsel (2011). Physalis peruviana L.: A rich source of bioactive phytochemicals for functional foods and pharmaceutFood Rev. Int. , 27, 259-273.

Swartwood, K. and J. Van Eck (2019). Development of plant regeneration and (Agrobacterium tumefaciens) mediated transformation methodology for (Physalis peruviana L.). Plant Cell, Tissue and Organ Culture (PCTOC), 137: 465-472.

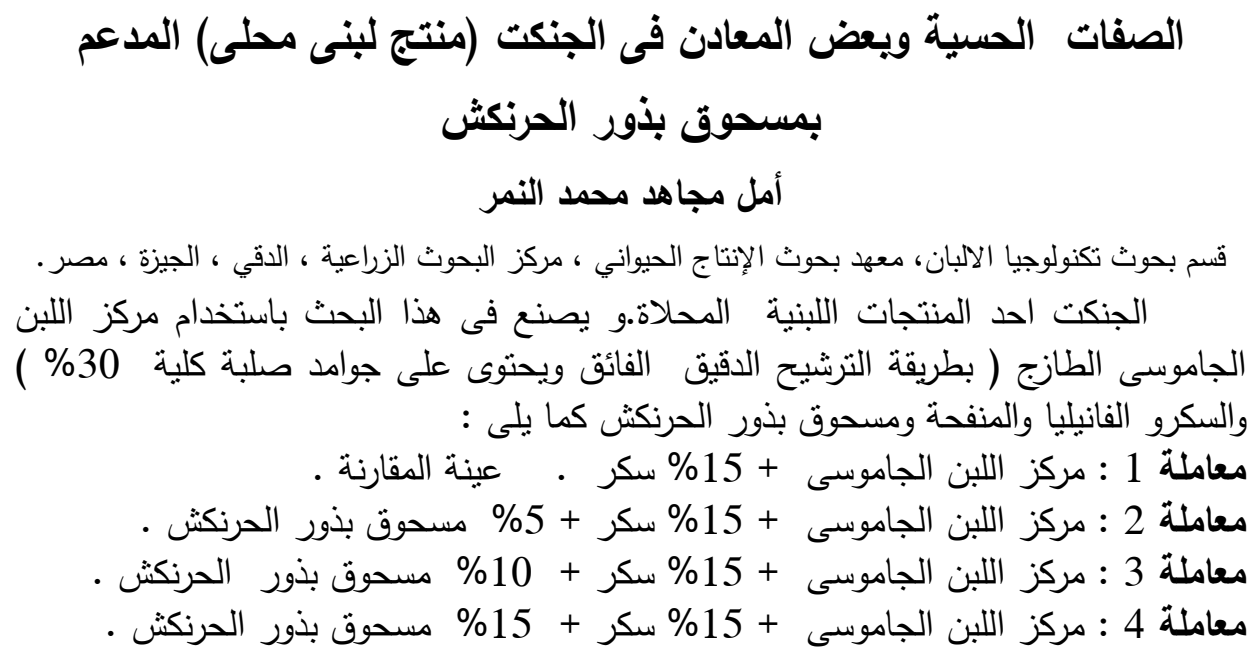




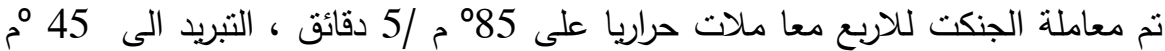

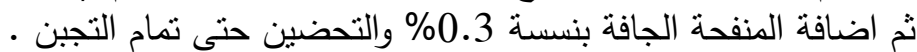
اظهرت النتائج مايلى: الجة

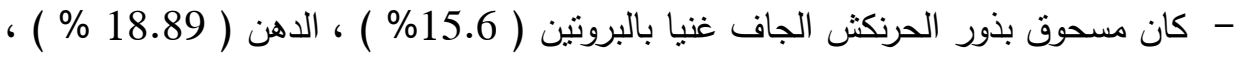
الالياف الغذائية ( 33.51\% ) ، الرماد ( 2.83\% ) وتميز بنشاطة المضاد للاكسدة

واحتواءة على بعض العناصر الهامة منل الكوبلت ، النحاس ، الحديد، ، الزنكل ، السلينيم ، - المنجنيز

- وجدت علاقة طردية بين نركيز المعادن في الجنكت ونسبة مسحوق بذور الحرنكث

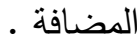

- كانت كل المعاملات مقبولة حسيا بصفة عامة وقريبة من معاملة المقارنة.وكانت افضل

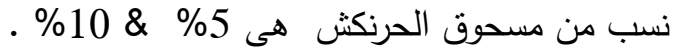

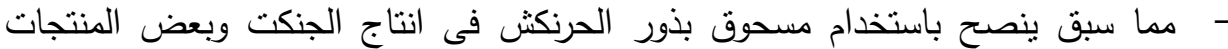

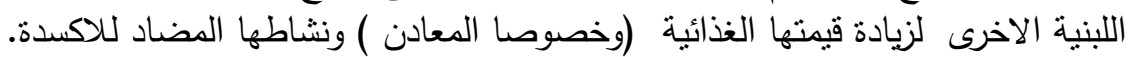
- كما يمكن استخدام الجنكت كناقل لفوائد مسحوق بذور الحرنكش. 